\title{
FODDER QUALITY IMPROVEMENT THROUGH INTERCROPPING AND FERTILIZER APPLICATION
}

\author{
Muhammad Arshad Ullah ${ }^{1}$, Nazir Hussain ${ }^{2}$, Helge Schmeisky ${ }^{3}$, MuhammadRasheed ${ }^{4}$, Maqsood \\ Anwar ${ }^{5}$ and Amir Saeed Rana ${ }^{6}$ \\ ${ }^{1}$ National Agricultural Research Center (NARC), Park Road, Islamabad, Pakistan; ${ }^{2}$ Shell Research and Technology \\ Centre,Doha, Qatar; ${ }^{3}$ Faculty of Organic Agriculture, University of Kassel, Witzenhausen, Germany; ${ }^{4}$ Department of \\ Agronomy, Pir Mehr Ali Shah Arid Agriculture University, Rawalpindi, Pakistan; ${ }^{5}$ Department of Wildlife \\ Management, Pir Mehr Ali Shah Arid Agriculture University, Rawalpindi, Pakistan; ${ }^{6}$ Endowment Fund Secretariat, \\ University of Agriculture, Faisalabad, Pakistan \\ "Corresponding author's e-mail:arshad_pak786@yahoo.com
}

\begin{abstract}
Present study investigated the improvement in fodder quality through intercropping of grass (Panicum maximum) and legumes (Vicia sativa and Vigna unguiculata) alone or coupled with fertilizer application under rain fed conditions at National Agriculture Research Center (NARC) Islamabad, Pakistan. In this experiment, intercropping at 33, 50 and $67 \%$ of grass and legumes and fertilizer application at the rates of 25,75 and $50 \mathrm{~kg} \mathrm{ha}^{-1}\left(\mathrm{~N}, \mathrm{P}_{2} \mathrm{O}_{5}\right.$ and $\left.\mathrm{K}_{2} \mathrm{O}\right)$ was applied. All three factors in this study not only increased fodder biomass production but also improved its quality. Fodder quality was improved by intercropping legumes with grass during first year of the study. Fertilizer and intercropping combinations proved highly positive, causing significant increase of Crude Protein in grass. The Crude Protein of pure legumes was higher than grass but fertilizer application did not affect to increase crude protein. Intercropping of legumes with grass along with fertilizer improved forage quality Total digestible nutrients (TDN) for livestock in grass were increased when forage legumes were intercropped with grass and when further supplemented with fertilizers. However, increasing effect of TDN was found significant only under combination of intercropping and fertilizer whereas these two factors individually failed to contribute in forage quality. Keywords: Fodder quality, Panicum grass, forage legumes, intercropping, fertilizer application
\end{abstract}

\section{INTRODUCTION}

Livestock is considered as very important component of agriculture sector in the world. The animal production contributes as milk, milk products, meat, wool, hides, bones and many associated products like manures etc for the benefits of mankind. Presently, there are 176.4 million livestock heads in Pakistan which contributes around 12\% towards GDP (Anonymous, 2014) while it was 169.5 million heads during 2012-13 which was accounting for $12 \%$ to GDP (Anonymous, 2013). Thus, there has been an increase of only $0.1 \%$ share in GDP in last year. This means the bad condition of this important sector and it also shows the in effective management of the vast resources department of the country. Therefore only $10-50 \%$ of their actual potential is being realized (Ali et al., 2001).

In Pakistan, livestock production is facing many challenges. Prices of animal origin foods are very high that are increasing everyday and out reaching reach of the poor communities. Livestock feed and green fodder is not only low and predictable results indicate less number of livestock instead to feed the accelerating population. Due to these factors the energy crisis, poor health of human and inflation are increasing day by day. These failures in production of food disturb social and environmental systems. One of the major problems hindering expansion in ruminant production of the country is the un-availability of good quality fodder in sufficient quantity (Sarwar et al., 2002). Production of good quality fodder is of great importance for economical animal production. Both quality and quantity of fodder are influenced by plant species (Kaiser and Piltz, 2002), stage of growth (Kim et al., 2001) and agronomic practices (Rehman and Khan, 2003).

Protein is the most demanded ingredient of ruminant feed, required substantially for milk or meat production as well as for reproduction. If feed crude protein is below 6-7\%, the microbial activity in the rumen is depressed due to lack of $\mathrm{N}$. The forage digestibility is related to changes in chemical composition, particularly of fiber, lignin and silica contents and to some extent crude protein (Bose and Balakarishnan, 2001). Livestock in the country is deficient in crude protein and total digestible nutrients by 38.1 and $24.0 \%$, respectively. Livestock receive 51, 38, 3, 6 and $2 \%$ of nutrients from green fodder, crop residues, grazing (bare lands and post harvest), cereal-by products and oil cakes meals, respectively (Sarwar et al., 2002).

Grass species Panicum maximum var. Tanzani is a tall growing (2-3 m), vigorous, coarse, tufted perennial and shows 
considerable variation in growth habit. It is a native grass of tropical and sub-tropical Africa. Leguminous plants supply the major portion of protein consumed by man either directly or indirectly through animals (Bose and Balakarishnan, 2001). The efficacy of feed utilization is an arithmetic value obtained by dividing the weight of body gain by the weight of feed consumed for that gain. Vetches (Vicia spp.) are legumes which are well adapted to winter growth in Mediterranean environments throughout the world on a variety of soil types and are used in West Asia and Australia for various purposes as green forage, hay, seed crop or green manure. Cowpeas (legume species Vigna unguiculata) native to South and Southern Asia are known for their diverse distribution and range of adaptation from humid sub-tropical to warmed cool temperate climate. It is highly palatable, nutritious and rich in protein, calcium and phosphorus than many other summer legumes (Bose and Balakarishnan, 2001). Legume forages are rich in proteins, minerals and vitamin. These are also used with diets that are largely consisting of grasses and their protein content often fall below minimum critical level. Therefore, increasing leguminous portion in animal diet not only increases protein content but also enhances voluntary intake and digestibility of entire diet (Parveen et al., 2001). Thus, keeping in view the limitations and constraints faced by the farmers involved in livestock production, present study was conducted to determine forage quality through grasslegumes intercropping, inoculation and fertilizer use.

\section{MATERIALS AND METHODS}

An appropriate study site was selected at National Agricultural Research Center Islamabad, leveled and soil samples were obtained from $0-15 \mathrm{~cm}$ soil depth. The samples were prepared and analyzed having soil $\mathrm{pH} 8.4$, ECe $0.53 \mathrm{dS}$ $\mathrm{m}^{-1}$, total $\mathrm{N} 0.037 \%$, available $\mathrm{P} 4.7 \mathrm{mg} \mathrm{kg}^{-1}$, extractible $\mathrm{K}$ $79.6 \mathrm{mg} \mathrm{kg}^{-1}$, O.M $0.53 \%$ having textural class Sandy Clay loam. Panicum maximum grass was planted in 2005 as perennial fodder. After its establishment, winter legume Vicia sativa, commonly known as vetch and summer legume (Vigna unguiculata commonly known as cow peas) were sown as inter crop in the established grass but after it's harvesting. Summer legume followed winter legume during next year. Two lines of legumes with four lines of grass were grown to establish T3 (33\% legumes) while there were three lines of each in case of T4 (50\% legumes) and four in case of T5 $(67 \%$ legumes). Fertilizer as a basal dose was applied to the treatments T6 to T10 at the rates of 25,75 and $50 \mathrm{~kg} \mathrm{ha}^{-1}(\mathrm{~N}$, $\mathrm{P}_{2} \mathrm{O}_{5}$ and $\mathrm{K}_{2} \mathrm{O}$ ) as urea, single super phosphate and sulphate of potash, respectively. The experiment was conducted under rain fed conditions and no irrigations were applied. Grass was harvested at panicle stage whereas legumes were harvested at $100 \%$ flowering. Fresh and dry matter yield, plant height and tillers were recorded. However, plant samples (grass as well as legumes) were obtained to assess the fodder quality when there was $50 \%$ flowering of legumes. Soil samples were obtained from each treatment separately after harvesting of fodder crops and analyzed for different parameters. The experiment was laid out using randomized complete block designs (RCBD) with 4 replications. The land was well prepared by plowing and planking after leveling. The grass Panicum maximum var. Tanzania tufts were planted during the first week of July at the onset of monsoon season as perennial grass. Plant to plant and row to row distance was kept as $50 \mathrm{~cm}$. A basal dose of fertilizer $\left(25 \mathrm{~kg} \mathrm{~N} \mathrm{ha}^{-1}, 75 \mathrm{~kg}\right.$ $\mathrm{P}_{2} \mathrm{O}_{5}$ and $50 \mathrm{~kg} \mathrm{~K}_{2} \mathrm{O} \mathrm{ha}{ }^{-1}$ ) was applied at the time of sowing in the second experiment, while no fertilizer was used in the first experiment. Hoeing was done twice after the sowing of legumes as inter-crop. The grass was harvested at the panicle stage. No irrigation was provided and fodder production totally depended on rains. Line sowing was done with the help of manual drill for Vigna unguiculata var. P-518 as summer legume and Vicia sativa as winter legume. The seeds of Vigna unguiculata and Vicia sativa were drilled with a seed rate of 90 and $75 \mathrm{~kg} \mathrm{ha}^{-1}$, respectively, having row to row distance $50 \mathrm{~cm}$. The legumes were harvested at $100 \%$ flowering stage .Crude protein (CP) and was determined by micro-Kjeldhal method (AOAC, 1994). Total digestible nutrients were calculated by the equation of Wardeh (1981).

$\% \mathrm{TDN}=-26.685+1.334(\mathrm{CF})+6.598(\mathrm{EE})+1.423(\mathrm{NFE})+$ $0.967(\mathrm{Pr})-0.002(\mathrm{CF})^{2}-0.670(\mathrm{EE})^{2}-0.024(\mathrm{CF})(\mathrm{NFE})-$ $0.055(\mathrm{EE})(\mathrm{NFE})-0.146(\mathrm{EE})(\mathrm{Pr})+0.039(\mathrm{EE})^{2}(\mathrm{Pr})$ Meteorological data on rainfall, humidity, pan evaporation, wind speed, sunshine hours and temperature during the study period were obtained from Water Resources Research Institute, NARC to elaborate and understand the experimental results under the light of climatic changes. During the study period i.e. 2005, 2006 and 2007, monthly average rainfall (mm) was 86, 104 and 118; wind speed $\left(\mathrm{km} \mathrm{day}^{-1}\right)$ 60, 51 and 46; pan evaporation $\left(\mathrm{mm} \mathrm{day}^{-1}\right), 4,4$ and 4; sunshine hours day ${ }^{-}$ ${ }^{1}, 8,8$ and 8 ; monthly maximum and minimum average temperature $\left({ }^{\circ} \mathrm{C}\right) 28,13,28$, and $14,28,13$; average maximum and minimum relative humidity (\%) was $83,49,81$ and 51 , 83 and 50 (WRRI,2007).The data obtained were subjected to statistical analysis using the STATISTIX statistical software (Version 8.1) and the mean values were compared using Least significant difference (LSD) multiple range test P: $0.5 \%$ (Steel and Torrie, 1997).

\section{RESULTS AND DISCUSSION}

Highly positive trend was observed by intercropping of legumes in grass during first year. However, fertilizer and intercropping combinations proved highly positive that caused a significant increase of $\mathrm{CP}$ in grass. The $\mathrm{CP}$ of legumes was too high than grass but fertilizer application did not yield so much as far this parameter was concerned. Intercropping treatments (33, 50 and 67\%) slightly increased $\mathrm{CP}$ percentages but these remained non significant. Vicia 
sativa legume had a little bit more crude protein than cowpeas but pattern of variation was almost similar with the exception that CP in case of $67 \%$ intercropping in the first year (Fig. 1 and 2). General improvement in crude protein of grass was also recorded in different treatments of the experiment also in the second year of the study (Fig. 2). Kardag and Buyukburc (2003) reported that $50 \%$ grass pea and $50 \%$ barley mixture produced highest crude protein yield and therefore, was recommended for Turkey. Sengol (2003) reported that legume mixtures with one or two grass species gave higher crude protein of the hay from the mixture than grasses alone that was due to large $\mathrm{N}$ harvests compared to pure stands of grasses. Similar trend was also shown by Kutozova et al. (2001), Sudesh et al. (2006), Hoffnan et al. (2004), Malikov (2004), Likhachev et al. (2003), Zimkova et al. (2002), Springer et al. (2001), Reynolds (2005), Rao et al. (2007), Elessesser (2004) and Berdhal et al. (2004) who reported the improvement of crude protein by intercropping of legumes and fertilization that might be due to accumulation of nitrogen Frame et al. (2005) concluded that animal performance is enhanced by high intake and nutritive value characteristics of legume-rich diets. Likhachev et al. (2003) recorded higher digestibility in legume-grass mixtures compared to pure crops. Kaiser and Combs (1989) and Azim et al. (2000) were also of the view that digestibility of legume and nonleguminous mixture was higher than non-leguminous crop that may be due to inclusion of high crude protein legumes.

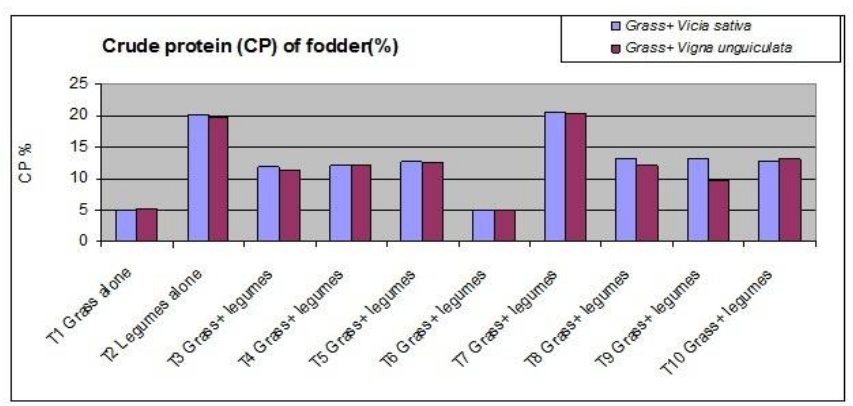

Figure 1. Effect of intercropping (grass-legumes) and fertilizer application on crude protein (CP) of fodder $(\mathrm{n}=4$ SD Vicia sativa $=0.677$ SD Vigna unguiculata $=\mathbf{0 . 7 4 8}$ )

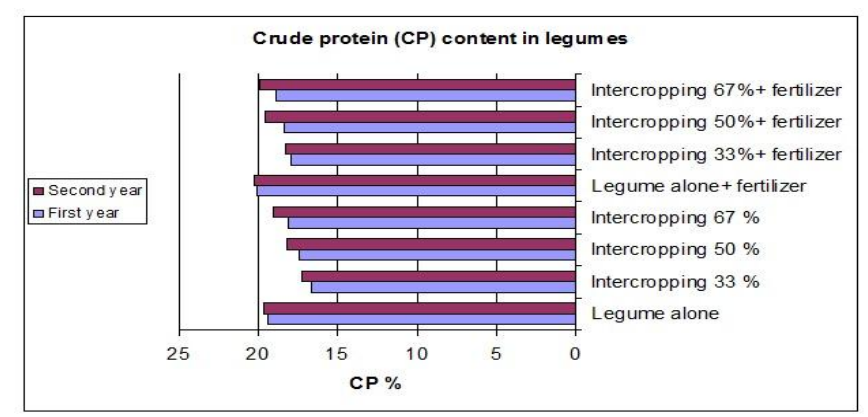

Figure 2. Year wise effect of intercropping and fertilizer on crude protein $(\mathrm{CP})$ of legumes $(n=4$ SD First year $=$ 1.017 SD Second year $=0.711)$

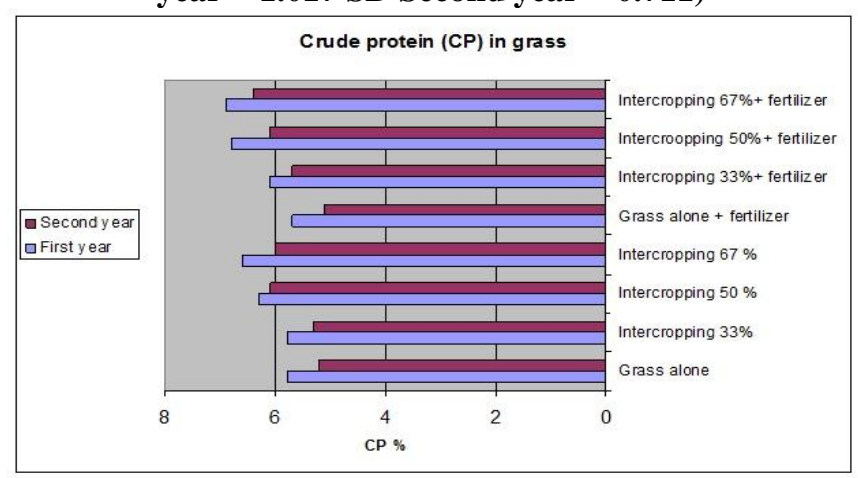

Figure 3. Year wise effect of intercropping and fertilizer on crude protein $(\mathrm{CM})$ of grass $(n=4$ SD First year $=0.987$ SD Second year $=0.723$ )

The main portion of NFE is soluble protein of carbohydrates. Solubility of proteineous carbohydrates is the important character of forage quality. Nitrogen free compounds increase the digestibility of grasses as well as legumes. Increasing effects of digestibility values were observed in case of grass as well as forage legumes (Table 1). Grass had more nitrogen free extract that was improved by the intercropping as well as combination of intercropping and fertilization. Increasing trend was also noted up to the $4^{\text {th }}$ crop. The nitrogen free extract increase was more in legumes than grass due to intercropping fertilizer. The $67 \%$ intercropping alone and its combination with fertilizer showed maximum nitrogen free extract in grass as well as forage legumes that might have increased the forage digestibility due to presence of soluble protein of the carbohydrates. Carbohydrates are the main source of balanced diet of livestock but their digestibility is low due to non solubility of proteins but nitrogen free extract included soluble protein of carbohydrates. Azim et al.(2000) reported that digestibility decreased by the presence of NDF and increasing the maturing stage. So NFE improved the quality of forage by increasing the voluntary intake due to the presence of soluble protein component of carbohydrates.

Many different terms are used to investigate nutritive value of fodders. These include TDN (Total Digestible Nutrients), digestible energy, digestible proteins, metabolized energy, net energy and efficiency of feed utilization. The feeding value of the forages may be divided into different values. A high percentage of protein is required in the diet of ruminants because production of milk and meat as well as reproduction mainly depends on the protein ingredient of the animal diet. Another important factor of feeding value is the digestibility by which animal converts forage to human foods. Digestibility mainly depends upon the availability of total digestible nutrients (TDN).

The TDN for livestock in grass were increased when forage legumes were intercropped with grass or further 
Table 1. Fertilizer effects on proximate composition of nitrogen free extract (NFE \%) at $50 \%$ flowering on dry matter basis.

\begin{tabular}{|c|c|c|c|c|c|c|c|c|c|}
\hline \multirow[t]{2}{*}{ Treatments } & & \multicolumn{4}{|c|}{ First year (2005-06) } & \multicolumn{4}{|c|}{ Second year (2006-07) } \\
\hline & & $\begin{array}{l}\text { Dry Matter } \\
\text { Grass/ Vicia }\end{array}$ & $\begin{array}{l}\text { NFE Grass/ } \\
\text { Vicia }\end{array}$ & $\begin{array}{c}\text { DryMatter } \\
\text { Grass/ } \\
\text { Cowpeas }\end{array}$ & $\begin{array}{c}\text { NFE } \\
\text { Grass/ Cow } \\
\text { peas }\end{array}$ & $\begin{array}{c}\text { DryMatter } \\
\text { Grass/Vicia }\end{array}$ & $\begin{array}{c}\text { NFE } \\
\text { Grass/Vicia }\end{array}$ & $\begin{array}{l}\text { DryMatter } \\
\text { Grass/ } \\
\text { Cowpeas }\end{array}$ & $\begin{array}{c}\text { NFE Grass/ } \\
\text { Cow peas }\end{array}$ \\
\hline T1 & Grass & 33.15 & $36.90 \mathrm{ef}$ & 34.40 & $35.17 \mathrm{i}$ & 33.75 & $38.87 \mathrm{~b}-\mathrm{f}$ & 33.61 & $38.40 \mathrm{f}$ \\
\hline $\mathbf{T} 2$ & Legume & 32.35 & $33.33 \mathrm{~h}$ & 36.50 & $36.83 \mathrm{~h}$ & 36.34 & $35.83 \mathrm{f}$ & 32.73 & $40.10 \mathrm{ef}$ \\
\hline T3 & Grass & 34.31 & 37.87 be & 33.73 & $36.77 \mathrm{hi}$ & 34.01 & $40.17 \mathrm{a}-\mathrm{e}$ & 32.37 & $40.17 \mathrm{ef}$ \\
\hline & Legume & 32.26 & $34.30 \mathrm{gh}$ & 34.36 & $39.40 \mathrm{~d}-\mathrm{g}$ & 35.33 & $35.97 \mathrm{f}$ & 34.33 & $43.67 \mathrm{bc}$ \\
\hline T4 & Grass & 34.17 & $37.37 \mathrm{e}$ & 34.49 & $36.27 \mathrm{hi}$ & 34.53 & 40.20 a-e & 32.16 & $40.20 \mathrm{ef}$ \\
\hline & Legume & 32.22 & $34.67 \mathrm{fgh}$ & 33.40 & $40.80 \mathrm{bcd}$ & 33.87 & $37.03 \mathrm{def}$ & 34.72 & $44.37 \mathrm{abc}$ \\
\hline T5 & Grass & 33.17 & 38.30 cde & 33.89 & $36.50 \mathrm{hi}$ & 33.08 & $41.23 \mathrm{abc}$ & 33.81 & 41.00 be \\
\hline & Legume & 33.30 & $38.47 \mathrm{~b}-\mathrm{e}$ & 33.25 & $39.70 \mathrm{c}-\mathrm{f}$ & 32.87 & $40.43 \mathrm{a}-\mathrm{d}$ & 33.25 & $43.57 \mathrm{bc}$ \\
\hline $\begin{array}{l}\text { T1 + } \\
\text { Fertilizers }\end{array}$ & Grass & 34.04 & $40.20 \mathrm{a}-\mathrm{d}$ & 33.03 & $37.87 \mathrm{gh}$ & 32.99 & $42.17 \mathrm{abc}$ & 34.12 & $42.97 \mathrm{bcd}$ \\
\hline $\begin{array}{l}\mathrm{T} 2+ \\
\text { Fertilizers }\end{array}$ & Legume & 30.90 & 36.93 ef & 32.29 & $39.07 \mathrm{efg}$ & 33.80 & $38.47 \mathrm{c}-\mathrm{f}$ & 30.97 & $43.17 \mathrm{bcd}$ \\
\hline $\mathbf{T} 3+$ & Grass & 32.48 & $40.63 \mathrm{abc}$ & 32.47 & 39.03efg & 32.01 & $42.83 \mathrm{ab}$ & 32.03 & $44.90 \mathrm{ab}$ \\
\hline Fertilizers & Legume & 31.88 & $34.80 \mathrm{fgh}$ & 33.75 & $41.23 \mathrm{abc}$ & 33.87 & $36.63 \mathrm{def}$ & 32.11 & $44.93 \mathrm{ab}$ \\
\hline T4+ & Grass & 34.58 & $40.43 \mathrm{abc}$ & 31.76 & $38.70 \mathrm{fg}$ & 31.33 & $35.80 \mathrm{f}$ & 34.87 & $44.53 \mathrm{abc}$ \\
\hline Fertilizers & Legume & 33.40 & $36.20 \mathrm{efg}$ & 31.39 & $42.67 \mathrm{a}$ & 31.45 & $36.40 \mathrm{ef}$ & 33.44 & $46.30 \mathrm{a}$ \\
\hline T5+ & Grass & 35.08 & $41.83 \mathrm{a}$ & 33.23 & $40.43 \mathrm{~b}-\mathrm{e}$ & 33.72 & $43.50 \mathrm{a}$ & 35.01 & $44.13 \mathrm{abc}$ \\
\hline Fertilizers & Legume & 34.07 & $40.70 \mathrm{ab}$ & 31.37 & $41.63 \mathrm{ab}$ & 31.88 & $42.47 \mathrm{abc}$ & 34.71 & $42.27 \mathrm{cde}$ \\
\hline- & LSD & - & 1.752 & - & 1.612 & - & 2.976 & - & 1.765 \\
\hline
\end{tabular}

supplemented with fertilizers (Fig.4, 5, 6). However, increasing effect of total digestible nutrients was found significant when fertilizer and intercropping were combined together whereas these two factors individually failed to contribute significantly. Such differences were recorded in both the years. But individual impact was exceptionally found significant only in first year cowpeas crop. Maximum TDN values were recorded in case of both the legumes when grown alone (Fig. 4, 5, 6) but quantum of this parameter decreased non-significantly when intercropping of these legumes was introduced within the grass.

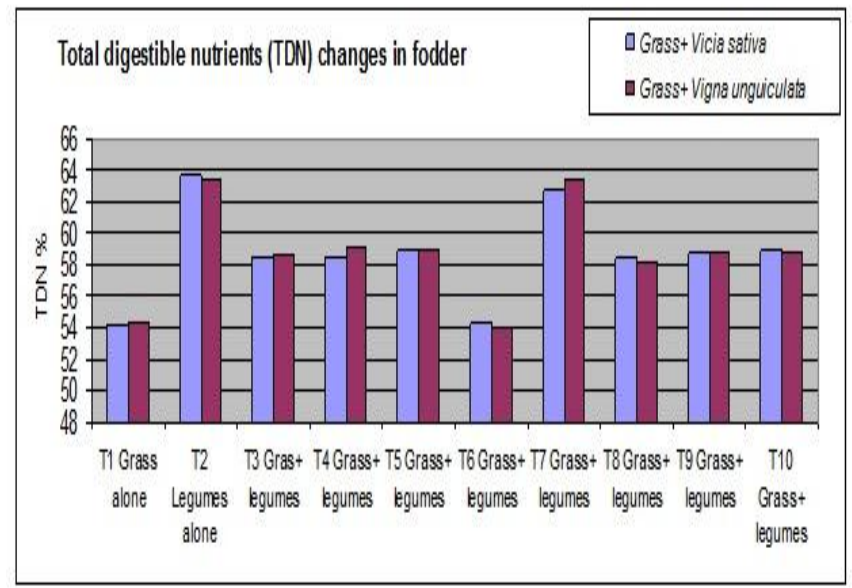

Figure 4. Effect of intercropping (grass-legumes) and fertilizer on total digestible nutrients (TDN) of fodder $(n=4$ SD Vicia sativa $=0.862$ SD Vigna unguiculata $=\mathbf{0 . 8 8 1}$ ) 


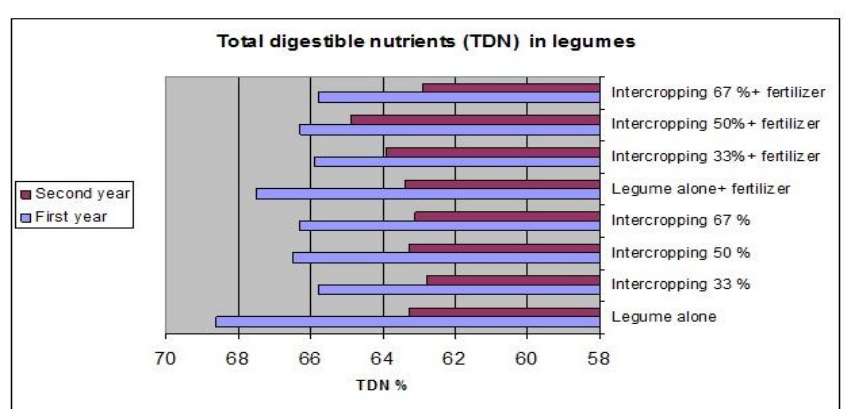

Figure 5. Year wise effect of intercropping (grasslegumes) lone and coupled with fertilizer on total digestible nutrients (TDN) in legumes $(n=4$ SD First year $=1.561$ SD Second year $=$ 0.871)

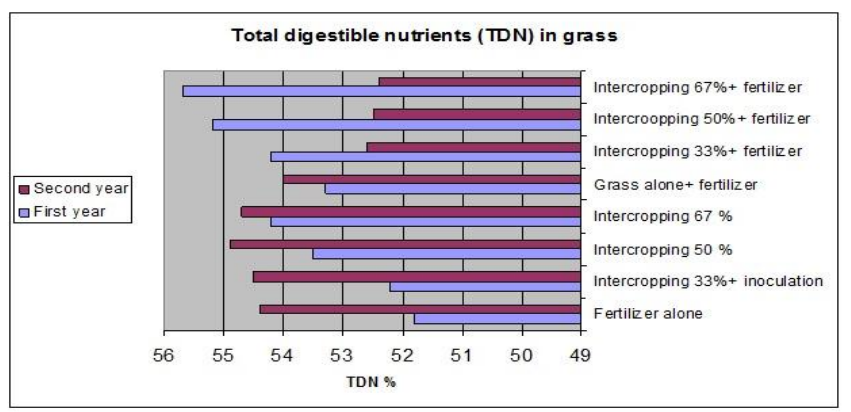

Figure 6. Year wise effect of intercropping and fertilizer on total digestible nutrients (TDN) content of grass $(n=4$ SD First year $=1.231$ SD Second year $=0.786$ )

Conclusion: Fertilizer application $\left(25,75\right.$ and $50 \mathrm{~kg} \mathrm{ha}^{-1}(\mathrm{~N}$, $\mathrm{P}_{2} \mathrm{O}_{5}$ and $\mathrm{K}_{2} \mathrm{O} @ 25,75$ and $50 \mathrm{~kg} \mathrm{ha}^{-1}$ respectively) not only increased biomass production but also some of the quality parameters of grass were positively affected resulting in increased crude protein as well as total digestible nutrients.

\section{REFFERENCE}

AOAC. 1994. Association of Official Analytical Chemists (AOAC). Official Method of Analysis, $12^{\text {th }}$ Ed. Washington, DC.

Ali, M., I.A. Qamar, A. Ali, M. Arshad and J. Iqbal. 2001. Evaluation of tropical grasses for forage yield and crude protein contents in the Pothwar Plateau of Pakistan. J. Biol. Sci. 1:466-467.

Anonymous. 2013. Statistics of Pakistan. 2013. Government of Pakistan. Ministry of Food, Agriculture and livestock (Economic wing), Islamabad, Pakistan.

Anonymous. 2014. Statistics of Pakistan. 2014. Government of Pakistan, Ministry of Food, Agriculture and livestock (Economic wing), Islamabad, Pakistan.

Azim, A., A.G. Khan, M.A. Nadeem and D. Muhammad. 2000. Influence of maize and cowpeas intercropping on fodder production characteristics of silage. Asian-Aust. J. Anim. Sci. 13:781-784

Berdahl, J.D., J.F. Karn and J.R. Hendrickson. 2004. Nutritive quality of cool-season grass monocultures and binary grass-alfalfa mixtures at late harvest. Agron. J. 96: 951955.

Bose, M.S.C. and V. Balakarishnan. 2001. Forage Production Technologies. South Asian Publishers, New Delhi.

Elessesser, M. 2004. Optimum management intensity of legume and grass based grassland swards. Proc. $20^{\text {th }}$ General Meeting of Euro. Grassland Federation, Switzerland; pp.510-512.

Harris, L.E. 1970. Nutrition Research Techniques for domestic and wild animals, Vol. 1. Anim. Sci. Dept., Utah State University, Logen, Utah, USA.

Hoffmann, R., F. Der, M. Gyovai and T. Fabian. 2004. The nutritional value of green fodder crops in pure stand and mixtures. Seria-Zootehnic-Si-Biotechnologii 60:147151.

Kaiser, R.M. and D.K. Combs. 1989. Utilization of three maturities of alfalfa by daring cows fed rations that contain similar concentration of fiber. J. Dairy Sci. 72:2301-2307.

Kaiser, A.G. and J.W. Piltz. 2002. Silage production from tropical forages in Australia. $13^{\text {th }}$ International Silage Conference, 11-13 September 2002; pp.8-9.

Kardag, Y. and U. Buyukburc. 2003. Effects of seed rates on forage production, seed yield and hay quality of annual legume-barley mixtures. Turkish J. Agric. For. 27:169174.

Kim, J.D., C.H. Kwon and D.A. Kim. 2001. Yield and quality of silage corn as affected by hybrid maturity, planting date and harvest stage. Asian Aust. J. Anim. Sci. 14:1705-1711.

Kutuzova, A.A., E.E. Provornaya, A.V. Rodionova and L.S. Trofimova. 2001. Ways of solving the problem of protein deficit in meadow fodder production. Kormoproizvodstov 3:10-14.

Likhachew, B.S., N. Leonova, V.V. Osmolovskii and Kistenev. 2003. Effectiveness of grain forage production in legume companion crops. Russian Agric. Sci. 7:5-9.

Malikov, M.M. 2004. A system-farming role of fodder production. Kormoproizvodstov 1:14-15.

Parveen, S., I.A. Qamar, A. Ali and M. Arshad. 2001. Effect of legume- grass mixture on forage yield and quality in Pothwar Plateau of Pakistan. J. Biol. Sci. 1:809-811.

Rao, S.C., B.K. Northup, W.A. Phillips and H.S. Mayeux. 2007. Inter-seeding novel cool-season annual legumes to improve Bermuda grass paddocks. Crop Sci. 47:168-173.

Rehman, A.U. and A. Khan.2003. Effect of feeding whole maize crop versus Mott grass silage on milk yield and its composition in Sahiwal cows. Sarhad J. Agric. 19:313316.

Reynolds, S.G. and I. Frame 2005. Prospects for temperate 
forage legumes grasslands development opportunities, perspectives, USA. Science Publisher, Inc.; pp.3-28.

Sarwar, M., M.A. Khan and Z. Iqbal. 2002. Feed resources for livestock in Pakistan. Int. J. Agric. Biol. 4:186-192.

Sengul, S. 2003. Performance of some forage grasses or legumes and their mixtures under dry land conditions. Euro. J. Agric. 19:401-409.

Springer, T.L., G.E. Aiken and R.W. McNew. 2001. Combining ability and binary mixtures of native, warm, season grasses and legumes. Crop Sci. 41:818-823.

Steel, R.G.D., J.H. Torrie and D.A. Dickey. 1997. Principles and Procedure of Statistics: A biometrical Approach. McGraw Hill Book Co., Inc. Singapore; pp.173-177.
Sudesh, R., B.S. Katochb and C.L. Marwah. 2006. Intercropping of forage crops with grasses: an innovative fodder production system for mid-Himalayan hills. Range Manag. Agrofor. 27:13-17.

Water Resources Research Institute. 2007. Agricultural Meteorological Field Station NARC, Islamabad, Pakistan.

Wardeh, M.F. 1981.Models for estimating energy and protein utilization for feeds. PhD Thesis, UtahState Univ. Logan, Utah. 